\title{
Ragnar Andreas Audunson* \\ Do We Need a New Approach to Library and Information Science?
}

https://doi.org/10.1515/bfp-2018-0040

\begin{abstract}
This article analyses the pressure against librarianship and library and information science stemming from digitization and the increased importance attached to libraries' role as meeting places and arenas for the public sphere. Both these developmental tendencies make many question the need of librarians as intermediaries between users and the sources of information. The navigating and searching for information in a digital world when the world itself has become a library, is far from trivial and the traditional competencies of librarians relating to searching for and finding information is as relevant as ever. LIS schools should also provide their students with theoretical tools helping them reflect upon the role and potential of libraries in relation to the challenges to upholding a sustainable public sphere in a digital and multicultural age. LIS schools should also convey to their students the historical continuity and legacy of libraries as a public sphere institution.
\end{abstract}

Keywords: Library as meetings place in the public sphere; arena; democracy; social processes; professional civic self-cultivation

\section{Brauchen wir einen neuen Ansatz für die Bibliotheks- und Informationswissenschaften?}

Zusammenfassung: Der vorliegende Beitrag analysiert den durch die Digitalisierung bedingten Druck auf das Bibliothekswesen und die Bibliotheks- und Informationswissenschaft sowie auf die zunehmende Bedeutung der Bibliotheken als Begegnungsorte und -arenen für die Öffentlichkeit. Beide Entwicklungstendenzen stellen die Notwendigkeit von Bibliothekaren als Vermittler zwischen Nutzern und Informationsquellen in Frage. Das Navigieren und Suchen nach Informationen in einer digitalen Welt, wenn die Welt selbst eine Bibliothek geworden ist, ist alles andere als trivial und die traditionellen Kompetenzen der Bibliothekare in Bezug auf das Suchen und Finden von Informationen sind so relevant wie eh und je. LIS-Ausbildungseinrichtungen sollten ihren Studenten auch die the-

*Kontaktperson: Prof. Dr. Ragnar Andreas Audunson,

Ragnar.Audunson@hioa.no oretische Werkzeuge zur Verfügung stellen, die ihnen helfen, über die Rolle und das Potenzial von Bibliotheken in Bezug auf die Herausforderungen einer nachhaltigen öffentlichen Sphäre im digitalen und multikulturellen Zeitalter nachzudenken. LIS-Ausbildungseinrichtungen sollten ihren Studenten auch die historische Kontinuität und das Erbe von Bibliotheken als Institutionen der öffentlichen Sphäre vermitteln.

Schlüsselwörter: Bibliothek als Ort der Öffentlichkeit; Arena; Demokratie; soziale Prozesse; Berufsethos; Bildung

\section{Introduction: LIS under pressure - is the field in need of a new approach?}

There are signs that librarianship is a profession under pressure. Dave Nicholas (2012) maintains that in the digital age the need for intermediaries, e.g. librarians, the sources of knowledge or experience is no longer present. Disintermediation is the key concept. In the digital age, people have direct access to those information pipelines, which in earlier times were reserved for a privileged few. One might dispute that: identifying and accessing relevant and reliable information is still far from trivial. But nevertheless Nicholas' view seems to be shared by many. A well-known university professor in computer science in Norway wrote an article in Norway's largest newspaper in 2012 where the main point was that he no longer needed the university library's or the university librarian's help to identify and access the research literature he needs. He can access what he needs via his own computer. ${ }^{1}$ Thus, he confirms Nicholas' concept of disintermediation. He does not need an intermediary between himself and the information. Again, one can argue that the databases he searches are organized by librarians and that it is due to the university library that he can access peer reviewed journals for free from his desk. But to the extent his perception of reality is widespread - wrong as it might be - it will affect the

1 Olsen (2012) 
legitimacy of using scarce resources on libraries in a negative way.

Also in public libraries, we find signs that the profession of librarianship is under pressure. In the Scandinavian countries, maybe first and foremost in Norway and Denmark, we can observe a tendency to employ people in professional positions in public libraries with other educational backgrounds than library and information science. In 2016, Oslo Public library opened a new and innovative branch for youngsters between 10 and 15 years of age in an inner city township with relatively severe social problems. When the professional positions in this new library was announced a number of relevant competencies and educational backgrounds were listed. Librarianship was not among them. If one attends a meeting for heads of departments and local branches in the Oslo public library today, a large proportion, maybe the majority will not have LIS as their educational background. That would have been unthinkable if we go back only $18-20$ years in time, to the turn of the century. There is a tendency to look for professionals with other educational backgrounds, also among librarians, as a change in the role of libraries, which calls for other skills and competencies than those taught in library and information science programs. The library's role as a meeting place in the community and its role as an arena for public debate and discourse are given increased weight. In Norway those roles were amended to the mission statement of the law on public libraries in 2013 and it is, as stated above, perceived as a new role among librarians as well as non-librarians, even though one can argue that they are firmly rooted in the professional traditions of librarianship already from the early years of the $20^{\text {th }}$ century.

The pressures described above are rooted, then, in two developmental trends: The first is digitization. It is digitization, which makes the professor in computer science referred to above, believe that he can access everything he needs from his computer without the help of a library or a librarian as an intermediary. The second trend is the increased preoccupation with libraries, in particular public libraries, as centers of experience ${ }^{2}$, as community meeting places and as arenas for the public sphere. These two trends are related. It seems, paradoxically, that digitization has led to a preoccupation with communities, not only web based, but also physical communities and meeting places - that which Söderholm and Nolin (2015) term the third wave of community engagement.

My conclusion, which I will elaborate below, can be summarized in three points:

1. I do not think Kai Arne Olsen and Dave Nicholas are right. In spite of the great amount of information accessible online, identifying it and accessing it is far from a trivial task. We see that clearly in the disciplines most dependent upon basing their research and practice on updated knowledge, e.g. medicine. There, librarians with the competencies need to perform systematic searches, securing that one finds that which is relevant, are indispensable parts of clinical teams and research groups. Educational program in LIS must see to it that we educate librarians with these competencies.

2. Much of the needed competencies related to the new role of libraries as meeting places, centers of experience and institutions of the public sphere are to be found in the field's traditions and in professional repertoires developed 100 years ago. These traditions should play a central role when developing educational programs relevant for that, which often is termed the new role of libraries, which, at the end of the day, is not so new at all. In addition, however, today's librarians have to have a profound understanding of public sphere theory, the ways in which a sustainable public sphere and conditions for a free and enlightened public discourse is threatened ant the potential and role of libraries in relation to these challenges.

3. That which is fundamentally new is that the role of librarians and libraries are set free from the demands of the physical collection. Educational programs and professional practice can focus upon the primary goals and social responsibility, not the demands of an instrument, i.e. the physical collection. Utilizing this freedom might be both threatening and challenging, but it can open up new possibilities for LIS.

2 In the languages belonging to the Germanic language family, the English term experience covers two concepts. The first is Erlebnis. An experience in this sense tends to be highly individual. My experience or "Erlebnis" from reading a novel or watching a theatre performance might be different from yours, but both experiences are equally valid. The other meaning of the term is Erfahrung, i.e., a way of learning, e. g., learning rooted in social practice as in a master-apprentice relationship. Then the participants via practice reach a common understanding, where the master's understanding has the upper hand. My

understanding is that when librarians talk about the experience library, the term covers the first concept Erlebnis. Carlsson (2013). 


\section{Library and information science - a professional discipline}

I take as my point of departure that library and information science is a professional science, where research aims at generating knowledge that can serve to develop and refine professional practice and educational program aims at education professional practitioners. In this respect, library and information science departments are similar to teacher training departments or departments for research and education in the different health professions. Professional sciences and professional educational programs have some important characteristics in common:

- They are multidisciplinary. A practitioner in medicine has gone through an educational program consisting subjects based in disciplines such as, for example, biology, physiology, psychology, pharmacy, the relationship between social conditions and health, to mention a few. A teacher must study the subject fields in which he or she is going to teach, for example math, chemistry and physics, as well as didactics and pedagogics. Although many professions are based in a core discipline, they cannot be reduced to that core. Medicine cannot be reduced to biology and library-and information science cannot be reduced to metadata and knowledge organization. The core of LIS has traditionally been knowledge organization, classification and cataloguing. Do adapting to the changes we live through in an adequate way imply a change in our perception of this field's core knowledge?

- Being a graduate from a scientifically based educational program is generally a precondition for being admitted into the profession. In times of rapid and profound environmental upheaval and turbulence that might change and be challenged. Are LIS in such a situation now and how can the field reacts adequately?

- Professional sciences are affiliated to some core institutions, for example health professions to hospitals and teachers to schools, and have to adapt to changes in these core institutions. Scholars in theoretical physics or in linguistics adapt to developments within their disciplines. As scholars, they do not have to care very much about social, political and institutional developments. Educational programs in the health sciences, although primarily affected by scientific developments, are also affected by changes in health policies, health institutions and demographic- and life style changes; educational programs in journalism are affected by the rapid and profound changes in the media structure and media policies stemming from digitiza- tion - and so is library and information science. Environmental changes might upset and lead to balances the knowledge structure of a profession. In a digital age, knowledge of relevance for digital warfare might increase in importance in educational programs at military academies at the expense of tactics and strategies when commanding a traditional infantry battalion. If not adapting, one might lose relevance. Are we in a similar situation in library-and information science?

- In all educational programs, there are elements that are ephemeral (but might be necessary to document that you are modern and up to date) and elements of lasting value. When I studied library and information science around 1980, we had some courses in library automation that are completely outdated today. The courses I took in indexing theory, however, provided me with knowledge and skills that are still relevant. Which part of the knowledge base and curriculum of our program are robust and relevant, which are of a more ephemeral nature?

- A professional education provides the students with skills and knowledge of a technical and instrumental character. One has to master these skills and competencies in order to achieve legitimacy from the environments. Almost just as important, however, is the role of professional educations in providing students with a professional identity based in professional ethics and norms, an ability to reflect upon the profession's social mission and responsibility and the profession's history. In an instrumental logic one analyses the relationship between the problem to be solved and accessible means and instruments in the professional repertoire. Which means optimized to possibility for efficient problem solving. In the normative logic, one analyzes the relationship between a situation and a set of norms constituting ones professional identity. "What kind of situation is this and what does a person like me, for example a librarian, do in a situation like this?"3 What does this role of a professional education imply for LIS today?

These are questions I will touch upon and propose some answers to in the following.

3 March and Olsen (1985). 


\section{Digitization, the world as a library and the need for librarians as guides into the informational world}

One fundamental effect of digitization is that information is no longer bound to physical collections in institutions such as libraries. One can say that the world has become a library, with a ubiquitous presence of information. That is the reason why the Norwegian professor in computer science can maintain that he has access to everything he needs from his computer and why Dave Nicholas can maintain that we no longer need intermediaries. We are all librarians now, as he formulates it.

And yes, it is correct that most information needs can be solved without involving a librarian or other information specialist. That is, however, also the case in traditional library use. Most people go to the library, or the Web, with relatively trivial information needs. They know exactly what they are looking for. If I want to find the best flight between Oslo and Berlin that will bring me to Berlin in due time before the opening of German Library Meeting in June 2018, that is an example of a trivial information need. I know what I am looking for and the focus of my search is clear from the start. I can manage it myself without any problems. Most library visits and most visits on the web are related to such trivial information needs. We know what we look for, which book, which author, which article, which piece of information. However, a student embarking upon the process of writing a master's dissertation on the effects of digitization on the role of librarians is facing an information task that is far from being trivial. He or she will probably need help from teachers, fellow students and from librarians. Moreover, the student in question will face different problems throughout the process of concluding the dissertation and will be in need different kinds of help.

In addition, although the average internet users feel that they can manage quite well and that information literacy is not a problem, we know from research that there might be discrepancies between self-perception and reality. With the exception of the sucking reflex, very few skills and competencies are given us by birth; the Gutenberg revolution did not automatically create literacy and reading skills and the digital revolution does not automatically provide us with information competencies. Recent research indicates that even among the concept of digital natives, possessing information skills simply because they have never known any other world than the digital one, is a myth. The concept of the digital natives itself is a myth ${ }^{4}$ and the information processing of these individuals tend to be shallow. ${ }^{5}$ They do need guidance and intermediaries. Gross and Latham (2009) report a study undertaken by Educational Testing Service. In a sample of 3,000 college students and 800 high school students, only a minority of thirteen per cent had the level of information literacy deemed to be necessary to be a successful student. They also found that those with a low level of literacy often had an inflated self-image of their own competencies.

In the future we will need librarians who are capable of navigating and searching in a world of complex information systems. Although Abbott (1998) might be right when he maintains that only a minority of librarians in the future will work directly with indexing and classification, competencies in these subjects are necessary in order to learn navigating and searching in information systems. LIS educations, therefore, still have to focus on these traditional LIS-skills, which Øivind Frisvold (2018), the former dean of LIS education at Oslo Metropolitan University has termed the hallmark of librarianship.

\section{Libraries as meeting places and public sphere institutions}

The role of libraries as institutions promoting democracy, freedom of expression and upholding a sustainable public sphere is an important part of the legitimacy of librarianship and libraries. That role is reflected in documents such as ALA's Library Bill of Rights, the UNESCO-manifesto on public libraries and in library legislation in several countries. The Swedish library law, for example, states that libraries shall promote democracy and the free formation of opinion, whereas the Norwegian libraries according to the mission statement in the law on public libraries shall be independent meeting places and arenas for public discourse in their communities.

Libraries as institutions for democracy and the public sphere are not only an issue relevant for public libraries. An issue such as Open Access is vital in relation to promoting an enlightened and informed public discourse and that issue is of particular importance for university libraries. One can also observe that university libraries to an increasing degree are arranging lectures and public debates, i.e.

4 Kirschner and De Bruyckere (2017).

5 Carr (2011). 
they are adopting working methods which hitherto have been typical for public libraries.

LIS researchers are preoccupied with libraries as public sphere institutions and as non-commercial meeting places with a democratic potential. Buschman $(2005,2016)$ Buschman and Warner (2016), Burnett and Jaeger (2008), Widdersheim and Koizumi (2015, 2017), Widdersheim (2017) are examples of researchers who have been preoccupied with libraries as public sphere institutions, utilizing public sphere theories in the tradition of Habermas. Jaeger and Fleischman (2007), Jaeger et al. (2013a, b,c) and Jaeger and Sarin (2016) are preoccupied with the political nature of librarianship and libraries as an institution for democracy, although the role of libraries in this respect relies more on anecdotal evidence than research. Johansson (2004) is preoccupied with libraries and librarians as intermediaries in a situation where the diminishing role of traditional media and the increasing role of direct communication between state authorities and citizens are making citizens more dependent upon the government's own version of their policies. Braman (2007) argues that the informational state transfers power from citizens to the state. In the informational state, the state knows more and more about the citizens, the citizens less and less about the state she maintains, and argues that expressing oneself in public in meaningful and efficient ways becomes more difficult than before. Can libraries compensate for this? Others, e.g. Audunson (2005) have been preoccupied with the potential of libraries in counteracting fragmentation and echo chambers in a multicultural and digital age.

The role of libraries as public sphere institutions is far from new. When it comes to public libraries, Wiegand (2015) documents very clearly that this has been an integral part of public librarianship since its birth in the last decades of the 19th century and the first decades of the 20th. University libraries developed as a part of the Humboldtian university revolution evaluating the search for knowledge for its own sake. An open science and a scientific public sphere presupposed communication channels and open access to scientific publications, which university libraries secured. It is vital that LIS root their curricula in relation to these issues in this historical continuity. This legacy represent a rich professional reservoir, which one also today can draw inspiration from and learn from; knowing that legacy is a part of what we could call the 'professional civic self-cultivation' (Bildung) - an "education" that might help prevent librarians falling prey to ephemeral tendencies.

The librarians we educate now, however, should have a profound knowledge of public sphere and democratic theory and they should be capable of reflecting upon the challenges we are facing in the digital and multicultural society with respect to upholding a public sphere and an integrating and enlightened public discourse and the potential of libraries in relation to these challenges.

In the Norwegian context there is a tendency that library directors maintain that the role of being a meeting place and arena for public discourse demand competencies first and foremost related to planning, arranging and moderating events. Such skills, however, are better acquired in practice. Educational programs should concentrate on conveying to the students a theoretical platform helpful in reflecting upon the challenges related to upholding a sustainable public sphere and the library's potential contribution.

\section{The freedom to focus upon the social mission}

One can define librarianship as a profession promoting social processes related to learning, knowledge sharing, cultural, and literary experiences based on organized collections of knowledge and literature. The collections are the instrument; the social processes represent the mission. In the pre digital age, the demands of the physical collections directed much of the planning and professional attention, also in LIS educations. Digitization gives a new freedom to focus upon the social mission instead of focusing upon administering a physical collection. Utilizing that freedom, however, might be challenging and threatening for educators as well as practitioners. It presupposes new ways of thinking.

\section{Some tentative conclusions}

My tentative conclusions, then, are.

1. In a world that has become a library and where information is ubiquitous, traditional library skills related to identifying and searching information, evaluating sources etc. are not obsolete. Information needs going beyond that which is trivial, will still be in need of traditional library competencies to be solved.

2. The role of libraries and librarianship with regard to underpinning a sustainable public sphere is increasing in importance. LIS-educations must equip their candidates with theoretical tools necessary in order to reflect upon the challenges the public sphere faces in a digital and multicultural world and the potential role of libraries in relation to these challenges. 
3. Library educations are not only there to convey professional skills to their students, but also 'professional civic self-cultivation' (Bildung), an important part of which is an understanding of the historical continuity the profession is a part of and which provides us with a context also for understanding today's challenges and for developing adequate responses to these challenges.

4. Digitization has liberated librarianship from focusing too strongly on the needs of the physical collection and provided us with the freedom of being able to focus upon the professions mission. Of stimulating social processes related to learning and cultural experiences. Utilizing that freedom is a challenge.

\section{References}

Abbott, Andrew (1998): Professionalism and the future of librarianship. In: Library Trends, 46 (3), 174-89.

Audunson, Ragnar A. (2005): The public library as a meeting place in a multicultural and digital context: The necessity of low intensive meeting places. In: Journal of Documentation, 61 (33), 429-41.

Audunson, Ragnar A.; Aabø, Svanhild (2013): From collections to connections: building a revised platform for library and information science. In: Information Research, 18 (3).

Braman, Sandra (2007): Change of State. Information, Policy and Power. Cambridge, MIT Press.

Burnett, Gary; Jaeger, Paul T. (2008): Small worlds, life worlds \& information behavior. In: Information Research, 13 (2).

Buschman, John (2005): On libraries and the public sphere. In: Library philosophy and practice, (e-journal), paper 11.

Buschman, John (2016): The Structural Irrelevance of Privacy: A Provocation". In: Library Quarterly, 86 (4), 419-33.

Buschman, John; Warner, Dorothy A. (2016): On Community, Justice, and Libraries. In: Library Quarterly, 86 (1), 10-24.

Carlsson, Håkan (2013): Den nya stadens bibliotek: om teknik, förnuft och känsla i gestaltningen av kunskaps- och upplevelsestadens folkbibliotek, Faculty of Humanities and Theology, Department of Arts and Cultural Sciences, Lund University, Lund.

Carr, Nicholas (2011): The shallows. What the internet is doing to our brains. New York, Norton and Company.

Frisvold, Øivind (2018): Interview with the former dean of HOAI Library department. In: Bok og bibliothek (forthcoming).

Gross, Melissa; Latham, Don (2009): Undergraduates' Perceptions of Information Literacy: Defining, Attaining and Self-Assessing Skills. In: College \& Research Libraries, 70 (4), 336-50.

Jaeger, Paul T.; Fleischmann, Kenneth R. (2007): Public Libraries, Values, Trust and E-Government. In: Information Technology and Libraries, December 2007, 34-43.
Jaeger, Paul T.; Bertot, John C.; Gorham, Ursula (2013a): Wake Up the Nation: Public Libraries, Public Policy Making and Political Discourse. In: Library Quarterly, 83 (3), 61-72.

Jaeger, Paul T.; Gorham, Ursula; Bertot, John C.; Sarin, Linday (2013b): Democracy, Neutrality and Value Demonstration in the Age of Austerity. In: Library Quarterly, 83 (4), 368-382.

Jaeger, Paul T.; Gorham, Ursula; Sarin, Lindsay; Bertot, John C. (2013c): Library, Policy and Politics in a Democracy. Four Historical Epochs. In: Library Quarterly, 83 (2), 166-81.

Jaeger, Paul T.; Sarin, Lindsay (2016): The Politically Engaged Public Library: Admitting and Embracing the Political Nature of Public Librarianship. In: Public Library Quarterly, 35 (4), 325-30.

Johansson, Veronica (2004): Public libraries as democratic intermediaries: some examples from Sweden. In: New Library World, 105 (1/2), 47-59.

Kirschner, Paul A.; De Bruyckere, Pedro (2017): The myths of the digital native and the multitasker. In: Teaching and Teacher Education, 135-42.

March, James P.; Olsen, Johan P. (1985): Rediscovering Institutions: the Organizational Basis of Politics. New York. Free Press.

Nicholas, David (2012): Disintermediated, decoupled and down. In: Cilip Udate, 29-31.

Olsen, Kai Arne (2012): Trenger vi universitetsbiblioteket? In: Aftenposten. Retrieved 20th of February 2018 . Available at https://w ww.aftenposten.no/meninger/i/oEp6V/Trenger-vi-Universitets biblioteket.

Söderholm, Jonas; Jan Nolin, Jan (2015): Collections Redux: The Public Library as a Place of Community Borrowing. In: The Library Quarterly, 85 (3), 244-60. https://doi.org/10.1086/681608.

Widdersheim, Michael M. (2017): Late, Lost or Renewed? A Search for the Public Library Sphere in Public Libraries. In: Information Research, 22 (1).

Widdersheim, Michael M.; Koizumi, Masanori (2015): Signal architectures of US public libraries: Resolving legitimacy between public and private sphere. In: Proceedings of the Association for Information Science and Technology, 52 (1).

Widdersheim, Michael M.; Koizumi, Masanori (2017): A communication system approach to the problem of public library legitimacy. In: Library \& Information Science Research, 39 (1), 23-33.

Wiegand, Wayne A. (2015): Part of Our Lives. A Peoples History of the American Public Library. Oxford: Oxford University Press.

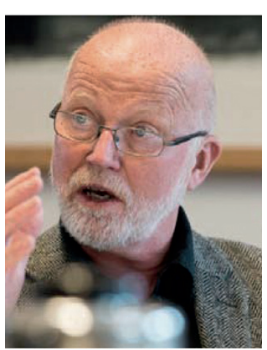

Prof. Dr. Ragnar Andreas Audunson Oslo Metropolitan University Department of Archivistics Library and Information Science Box 4, St. Olavs Plass NOR-0130 Oslo Norway Ragnar.Audunson@hioa.no 